https://doi.org/10.52449/1857-4114.2020.36-2.04

CZU: 796.032(478.9)

\title{
THE OLYMPIC MOVEMENT AS A TOOL FOR PUBLIC DIPLOMACY OF THE REPUBLIC OF MOLDOVA: PROBLEMS OF FORMATION AND DEVELOPMENT
}

\author{
Popov Anton ${ }^{1}$ \\ ${ }^{1}$ Academy of Public Administration, Chisinau, Republic of Moldova
}

\begin{abstract}
The article analyzes the process of institutionalization of the Olympic Movement in the Republic of Moldova, as well as the formation of the normative base of great achievement sport and its role as an instrument of foreign policy and a factor of soft power of the Moldovan State. In this regard, the author examines the continuity in the development of sports, in accordance with the two historical and political periods of the Moldovan statehood - "Soviet" and "Post-Soviet", through a comparative analysis of specific sports achievements. In this context, the author examines the main reasons for the slowdown in the development of the Olympic movement, including through the prism of content analysis the leaders of this structure, as well as the admission of systemic errors associated with insufficient funding of Moldovan sports, the lack of a legal framework for sponsoring performance sports, and the loss of the system for training highly qualified coaches.

Keywords: Olympic Games, Olympic Movement of the Republic of Moldova, International Olympic Committee, National Olympic Committee of the Republic of Moldova, national sports federations, great achievement sports, public diplomacy, sports diplomacy, "soft power".
\end{abstract}

Sport in the Republic of Moldova, as a means of mediatization of the country on the world stage and the formation of its positive image, manifested itself only in the early 1990 s, several months after the adoption of the Declaration of Sovereignty (June 23, 1990) by the Supreme Soviet of the Moldavian SSR [1]. The main task of the sports bureaucracy and athletes - representatives of the elite sport of that period, was to show the very fact of its existence, its functionality, including in the field of sports, through sports performances outside the emerging state. An initiative group of eight people, including the Olympic champions Tudor Casapu and Nikolai Zhuravsky, as well as eminent trainers Petru Caduc and Gheorghe Cucharski, appealed to the Parliament and the Government of the MSSR with an appeal to support the Constituent Congress of the National Olympic Committee of Moldova, which in the future was supposed to provide development of the
Olympic Movement in Moldova, as well as the participation of Moldovan athletes in international competitions [2, p.1].

The National Olympic Committee (NOC) of the Republic of Moldova was established on November 29, 1991, and in March 1992, before the Olympic Games in Barcelona, by the decision of the International Olympic Committee (IOC), it was conditionally recognized, signed by the IOC President and his four deputies [3, p.62-63]. Simultaneously with the NOC of Moldova, 11 more National Olympic Committees of the former Soviet republics received similar recognition, which, with the exception of the Baltic republics, represented a single team (national team) at the 1992 Summer Olympic Games in Barcelona. This was the last joint performance of former Soviet athletes at any international competition. A year later, world sporting events (September 24, 1993) the NOC of Moldova receives full recognition from the IOC, thus obtaining the 
right to participate in the Olympic Games and speak on behalf of the Republic of Moldova $[3$, p.62-63].

These were the first steps towards the institutionalization of Moldovan sports as an actor in the internal political as well as international and interstate relations of the Republic of Moldova. Further, in the late 1990, the Law on Physical Culture and Sports was adopted (No. 330-XIV of 25.03.1999), which provided, albeit with some delay, some assistance in the development of national sports in the Republic of Moldova [4].

In the context of the analyzed issue, the law contains two chapters - the fifth and the seventh, devoted to the "sport of great achievements" and, accordingly, "international sports relations". These sections contain provisions on a specific and, in a sense, an obsessive role of the state in the preparation of "high-class athletes - members of national teams for international competitions", which are financed "within the funds provided by the state budget ...". According to Article 25 - the Moldovan state assumes the responsibility of monitoring compliance with the conditions of "negotiating, concluding conventions, international treaties and agreements in the field of physical culture and sports" [4].

Analysis of this law prompts us to think that the state was not only ready to use the sport of great achievements as an instrument of foreign policy conducted by public diplomacy or exercised by "soft power", it intends to create this "instrument" by itself, consolidate it through financial support from the state budget and be responsible for its effectiveness and compliance with all conditions for the conduct and execution of contracts in the field of sports. Thus, by legislative means, conditions are created when the "instrument" is, most likely, the state in realizing the interests of national sports, and not vice versa. Based on this situation, one should not expect great sports achievements, relying on the modest financial capabilities of a developing state. In other words, given the economic potential and financial resources, the Moldovan state, by clearly linking the financing of sports to its own budget, can only hinder its progressive development.

Other important documents for the functioning and further development of Moldovan sports are the Resolutions of the Government of the Republic of Moldova No. 356 of March 26, 2003 [5] and, respectively, No. 176, of March 15, 2019 - "On Approval of the Regulation on the Activities of National Sports Federations" [6]. These two resolutions differ not only in terms of text and the number of provisions (the second document, being more complex), but also in content. A government decree in 2019 gives Moldovan sports more autonomy and less obtrusiveness from the state.

If, according to an earlier adopted resolution, the federations had a seal with the emblem of the Republic of Moldova, then in the 2019 Resolution, these structures are declared as non-profit organizations with a seal with their name. The deprivation of federations of the main state symbol means their administrative alienation, carrying out their activities on the basis of the Constitution of the Republic of Moldova and the relevant legislative acts [6].

In 2012, according to the order of the Government of the Republic of Moldova No. 1113-659 of August 10, 2012, the Strategy for the Development of Physical Culture and Sports (2013-2020) was developed. According to the authors of this document, its fundamental goal was to determine the main directions, as well as the methodological foundations of the development of physical culture and sports in the specified period. It is noteworthy that two subsections of the Strategy are entirely devoted to the issues of increasing the competitiveness of Moldovan sports in the international arena and, accordingly, international sports policy [7].

In addition to analyzing existing problems, the author points out the main directions and priorities of the development of Moldovan 
sports as an instrument of foreign policy, public diplomacy and the formation of the country's image abroad. Among the many proposals for improving the activities of the government and sports structures in this direction, one can note: the conduct of international sports policy in the spirit of friendship and patriotism; increasing the representation of Moldovan sports specialists in international sports organizations; preparation and promotion of Moldovan representatives to the international refereeing bodies of various sports federations, etc. [7].

Judging by the basic documents, in general, sports and sports structures of the Republic of Moldova have the necessary legislative and conceptual basis for their effective functioning, however, practice shows that due to the lack of due attention from the state, as well as some legislative distortions, sport has not become an effective tool public diplomacy and the creation of the country's image abroad, through "soft power" in the field of sports.

Considering the fact that the Olympic Movement is an expression of the essence of elite sport and practically all sports and federations representing them are focused in it, we will consider the development of Moldovan Olympism through the prism of two historical periods, conventionally designating them as "Soviet" and "PostSoviet". The first period characterizes the development of high-performance sports and the Olympic movement in the MSSR, and the second - in the sovereign Republic of Moldova. There is a clear historical continuity between these two periods.

The first participation of MSSR athletes in the Olympic Games took place in 1960. We are talking about the Rome Olympics, in which two athletes made their debut - Gusman Kosanov and Valentina Maslovskaya, as part of the USSR Olympic team. Kosanov in the $4 \times 100$ relay, won a silver Olympic medal,
Maslovskaya - European champion at that time, took the 4th place [8].

The representatives of the MSSR did not participate in the 1964 Olympic Games, which were held in Tokyo, however, at the next 1968 Olympics, three Moldovan athletes were invited to the Olympic team, who made their debut in Mexico City, as canoeists, two of whom - Naum Prokupets and Mikhail Zamotin won the Olympic bronze medal [9]. The next Olympic Games, held in 1972 in Montreal, turned out to be very successful for the athletes of the MSSR, who were represented in 4 sports: Yuri Filatov, the captain of the K-4 team, won the gold Olympic medal for the first time [10]. At the 1976 Olympic Games in Montreal, the MSSR was represented by two athletes. One of whom from Tiraspol Larisa Aleksandrova (after marriage - Popova) won a silver Olympic medal in the $4+1$ rowing [11]. After the boycott of the 1984 Olympics in Los Angeles, the participation of Moldovan athletes, members of the USSR Olympic team in the 1988 Olympic Games in Seoul, was marked by the greatest success in the history of Olympic sports in Moldova: Nikolai Zhuravsky becomes a two-time Olympic champion in C-2, 500 and 1000 meters [12]; Igor Dobrovolsky becomes an Olympic champion in the USSR national football team [13]; Yuri Bashkatov wins a silver medal in the top four in swimming $100 \mathrm{~m}$ [14]; Timofey Skryabin became the bronze medalist [15], and Natalya Rusnachenko, being the goalkeeper of the Soviet Union national handball team, also won a bronze medal [16]. On this triumphant note, the first stage of the history of the Olympic Movement in Moldova ends, which became not only an effective platform for the development of further Olympic successes of Moldovan athletes, but ensured reliable continuity in the transfer of professional experience in training national Olympians, as evidenced by the results of the Olympic team of the Republic of Moldova shown at the Olympic Games 1992 in Barcelona. 


\section{Medals won by Moldavian athletes of the MSSR as part of the USSR Olympic team [30]}

\begin{tabular}{|c|c|c|c|c|c|c|c|c|c|c|c|c|c|}
\hline \multirow{2}{*}{$\begin{array}{c}\text { Olympic } \\
\text { Games }\end{array}$} & \multicolumn{3}{|l|}{ II.Individual championship } & \multicolumn{3}{|c|}{ II. Team Championship } & \multicolumn{3}{|c|}{ III. Team Championship } \\
\hline & Gold & Silver & Bronze & Total & Gold & Silver & Bronze & Total & Gold & Silver & Bronze & Total \\
\hline $\begin{array}{c}\text { Summer } \\
\text { Olympic } \\
\text { Games }\end{array}$ & 1 & 1 & 2 & 4 & 4 & 4 & 4 & 12 & 4 & 4 & 4 & 12 \\
\hline $\begin{array}{c}\text { Based on } \\
\text { the results } \\
\text { of all } \\
\text { Games }\end{array}$ & 1 & 1 & 2 & 4 & 4 & 4 & 4 & 12 & 4 & 4 & 4 & 12 \\
\hline $\begin{array}{c}\text { Summer } \\
\text { Olympic } \\
\text { Games }\end{array}$ & I. Individual championship & Gold & Silver Team Championship & Bronze & Total & Gold & Silver & Bronze & Total & Gold & Silver & Bronze & Total \\
\hline $\begin{array}{c}1960 \\
\text { Rome }\end{array}$ & 0 & 0 & 0 & 0 & 0 & 1 & 0 & 1 & 0 & 1 & 0 & 1 \\
\hline $\begin{array}{c}1976 \\
\text { Montreal }\end{array}$ & 0 & 0 & 0 & 0 & 0 & 1 & 0 & 1 & 0 & 1 & 0 & 1 \\
\hline $\begin{array}{c}1980 \\
\text { Moscow }\end{array}$ & 0 & 1 & 0 & 1 & 1 & 0 & 0 & 1 & 1 & 0 & 0 & 1 \\
\hline $\begin{array}{c}1988 \\
\text { Seoul }\end{array}$ & 0 & 0 & 1 & 1 & 3 & 1 & 2 & 6 & 3 & 1 & 2 & 6 \\
\hline $\begin{array}{c}1992 \\
\text { Barcelona }\end{array}$ & 1 & 0 & 1 & 2 & 0 & 1 & 2 & 3 & 0 & 1 & 2 & 3 \\
\hline
\end{tabular}

So, the second stage of the Olympic Movement in Moldova begins with the participation of Moldovan athletes, as representatives of an independent state, in the Barcelona Olympics. It should be noted that, with the exception of the three Baltic republics, 12 national teams of the former Soviet republics formed the United Olympic Team. Especially for this occasion, the IOC Olympic protocol was changed, according to which the Olympic flag was raised and the Olympic anthem of the International Olympic Committee was raised at the awards ceremony for team competition athletes, and the national flag was raised and the national anthem of the athlete was sounded at the awards ceremony for representatives of individual competitions.
Despite a certain structural disunity, the United Team nevertheless took first place in the unofficial medal standings, having won 112 medals, of which 45 were gold [17].

Some of these achievements also belonged to Moldovan athletes: Tudor Casapu, weightlifting - Olympic gold medal [18]; Vyacheslav Gorpishin, handball - Olympic gold medal [19]; Yuri Bashkatov, swimming Olympic silver medal [14]; Natalia Valeeva, archery - two bronze medals [16]; Sergey Markoch and Alexey Vdovin, water polo bronze medals [20].

Our thesis that the success of Moldovan athletes at the 1988 Olympic Games in Seoul ensured continuity and success at the Barcelona Olympic Games, thereby forming the basis for 
the further development of Olympic sports in the Republic of Moldova, is confirmed by the above results. However, it should be noted that soon all this potential was wasted due to the already indicated reasons: the rigid binding of elite sport to the state and the state budget, which logically follows the growth of the bureaucratic bodies, the weakening of the coaching staff with small funding and an attempt to compensate for the quality of training of athletes by increasing the number of participants in various international competitions.

Dynamics of the participation of Moldovan athletes in the Olympic Games [30]

\begin{tabular}{|l|c|c|c|c|c|}
\hline $\begin{array}{c}\text { Summer Olympic } \\
\text { Games }\end{array}$ & Participants & Men & Women & Sport & Disciplines \\
\hline 1996 Atlanta & 40 & 35 & 5 & 11 & 40 \\
\hline 2000 Sydney & 34 & 29 & 5 & 7 & 34 \\
\hline 2004 Athens & 33 & 26 & 7 & 8 & 31 \\
\hline 2008 Beijing & 29 & 21 & 8 & 8 & 28 \\
\hline 2012 London & 20 & 12 & 8 & 9 & 19 \\
\hline 2016 Rio de Janeiro & 23 & 14 & 9 & 9 & 22 \\
\hline 2020 Tokyo & & & & & \\
\hline
\end{tabular}

\begin{tabular}{|l|c|c|c|c|c|}
\hline $\begin{array}{c}\text { Winter Olympic } \\
\text { Games }\end{array}$ & Participants & Men & Women & Sport & Disciplines \\
\hline 1994 Lillehammer & 2 & 1 & 1 & 1 & 4 \\
\hline 1998 Nagano & 2 & 1 & 1 & 1 & 4 \\
\hline 2002 Salt Lake City & 5 & 3 & 2 & 3 & 9 \\
\hline 2006 Turin & 6 & 3 & 3 & 3 & 8 \\
\hline 2010 Vancouver & 7 & 5 & 2 & 4 & 10 \\
\hline 2014 Sochi & 4 & 3 & 1 & 4 & 5 \\
\hline 2018 Pyeongchang & 2 & 2 & 0 & 2 & 3 \\
\hline
\end{tabular}

In this context, it should be noted that at the Olympic Games in Atlanta (1996), 40 athletes were sent, and they won only two medals - silver and bronze [21]; 34 athletes took part in the Olympic Games in Sydney (2000) - they also won two medals of the same dignity [22]; at the 2004 Olympics. in Athens, 33 athletes participated, but none of them received Olympic medals [23]; The
Olympic Games in Beijing (2008) were marked by the participation of 28 Moldovan athletes, of which only one won a bronze medal [24]; at the Olympic Games in London (2012) 20 athletes were sent, two of whom won bronze medals [25]; The Olympic Games in Rio de Janeiro in 2016, in which 23 athletes participated, did not become more effective, only one of them was awarded a bronze medal [26]. 
Total number of medals won by athletes from the Republic of Moldova at the Olympic Games [30]

\begin{tabular}{|l|c|c|c|c|}
\hline \multicolumn{1}{|c|}{ Medals } & Gold & Silver & Bronze & Total \\
\hline Summer Olympic Games & 0 & 2 & 6 & 8 \\
\hline Winter Olympic Games & 0 & 0 & 0 & 0 \\
\hline Based on the results of all Games & 0 & 2 & 6 & 8 \\
\hline
\end{tabular}

The number of medals won by athletes of the Republic of Moldova in the Olympics [30]

\begin{tabular}{|c|c|c|c|c|c|}
\hline A place & $\begin{array}{c}\text { Summer Olympic } \\
\text { Games }\end{array}$ & Gold & Silver & Bronze & Total \\
\hline 78 & 2016 Rio de Janeiro & 0 & 0 & 1 & 1 \\
\hline 75 & 2012 London & 0 & 0 & 2 & 2 \\
\hline 80 & 2008 Beijing & 0 & 0 & 1 & 1 \\
\hline$(-)$ & 2004 Athens & 0 & 0 & 0 & 0 \\
\hline 61 & 2000 Sydney & 0 & 1 & 1 & 2 \\
\hline 58 & 1996 Atlanta & 0 & 1 & 1 & 2 \\
\hline
\end{tabular}

\begin{tabular}{|c|l|c|c|c|c|}
\hline & $\begin{array}{l}\text { Winter Olympic } \\
\text { Games }\end{array}$ & Gold & Silver & Bronze & Total \\
\hline$(-)$ & 2006 Turin & 0 & 0 & 0 & 0 \\
\hline
\end{tabular}

In this context, it is of some interest to consider the reasons for the collapse of the Olympic movement in the Republic of Moldova, from the point of view of understanding the problem from within this process. In this sense, we examined, through the prism of content analysis, a series of interviews with the Chairman of the NOC of the Republic of Moldova Nikolai Zhuravsky an outstanding athlete - canoeist, multiple champion of Moldova, multiple champion of the USSR, eight-time world champion and two-time Olympic champion, silver medalist of the Olympic Games, best Moldavian athlete of the XX century, President of the National Olympic Committee of the Republic of Moldova since 2001. In all his speeches, the insufficient attention of the Moldovan state to the Olympic sport, as well as its weak funding, is emphasized. So in 2007 Zhuravsky declared: "... since the proclamation of the sovereignty of the Republic of Moldova, much has been lost in the development of sports. During the transition period, many coaches left ... The lack of monetary incentives hit sports very hard. What collapsed in ten years is difficult to restore in two or three years ... The development of sports largely depends on the country's economy. Sport needs serious investments" [27]. These words, on the whole, correct and fair, sound in different variations in almost all of his interviews.

Thus, two years later, in another interview, Zhuravsky stated: "These last 15-20 years have not only been stagnant - we have a decline ... Everything that is in the country today is the result of that Soviet school." And then he rhetorically asked (by that time holding the post of chairman of the IOC for 8 years): "Where, I ask, is our own national system of selection, selection of athletes? Where is our initial training system for athletes? Where are our homebrew trainers? Where is the system for training an athlete's transition from mass sports to high-performance sports? There is no such thing in Moldova ..." [28].

Judging by the weak Olympic results that have shown themselves since the Olympic 
Games in Atlanta (1996), the Moldovan state is behaving paradoxically - on the one hand, it binds high-performance sports through legislation to the sphere of its competences and financial resources, on the other hand, it alienates it, including small funding, thus slowing down its development and thereby exerting a destructive influence on its role as an instrument of foreign policy and the formation of a positive image of the Republic of Moldova in the international arena. The current state of affairs is confirmed by the words of the chairman of the NOC "Surprisingly, since I headed this public organization, we have not received a single leu from the country's budget for the development of the Olympic movement" [29].

Another paradox of this situation is that a person who has been at the head of the Olympic Movement for almost 20 years, and having at a certain period of time the status of a member of the Moldovan parliament, failed to convince the "power" he represented, including in the NOC of Moldova, the need for development Olympic sports as a necessary component of the diplomatic relations of the Moldovan state. In this situation, we do not discuss the quality of its activities, we are interested in the situation of systemic ignorance by the Moldovan authorities of everything that can bring benefit and added value to the country, exerting a destructive effect on everything that could be capitalized and developed for the benefit of the development of the state.

Despite the existing problems in Moldovan sports: insufficient attention from the state; lack of legislative tools for sponsoring; weakening material and technical base; insufficient funding; the loss of a school for training high-class coaches and, most importantly, in our opinion, the need to use sports as a tool to consolidate society and promote a decent image of the country in the international arena, which, in our opinion, is not fully realized, sport nevertheless plays a significant role in the social, political, economic and international life of the country.

\section{References:}

1. Declaraţia suveranităţii Republicii Sovietice Socialiste Moldova Nr. 148-XII din 23.06.90. https://www.constcourt.md/pageview.php?l=ro\&id=275\&idc=11\&t=/Prezentare-generala/Premiseistorice/Declaratia-suveranitatii/?l=ro\&id=275\&idc=11\&t=/Prezentare-generala/Premise-istorice/Declaratiasuveranitatii/ (дата посещения: 23.09.2020)

2. Apel către Parlament, Guvern, formațiunile obștești, intelectualitate, către toate forțele patriotice ale republicii. (1990). În: Moldova Sportivă, Nr. 89, p.1.

3. Donets N., Juravschi L., Vasilianov C., (2016). 25 de ani ai Comitetului Național Olimpic și Sportiv din Republica Moldova. Chişinău: „Elan Poligraf”. 284 p.

4. Закон о физической культуре $u$ cnорте $N$ 330-XIV от 25.03.1999. http://cnas.md/libview.php?l=ru\&idc=183\&id=547\&t=/zakonodatelictvo/zakoni/zakono-fiziceckoi-kuliturei-cporte-N-330-XIV-ot-250399 (дата посещения: 25.09.2020)

5. Постановление Правительства Республики Молдова об утверждении Положения об организачии и функиионировании национальных спортивных федераџий № 356 от 26-03-2003. В: „Monitorul Oficial” от 04-04-2003, № 62-66, статья № 381.

6. Постановление об утверждениии Положения о деятельности национальных спортивных федераиий Nr.176 om 15.03.2019. B: „Monitorul Oficial” от 22.03.2019, № 101-107, статья № 206.

7. Стратегия развития физической культуры и спорта в Республике Молдова на период 2013202022.

http://old.mts.gov.md/sites/default/files/document/attachments/strategiya razvitiya fizicheskoy kultury i_sporta_v_respublike_moldova_na_period_2013-2020_gg.pdf (дата посещения: 25.09.2020)

8. Харченко Б. Легкая атлетика. https://press.try.md/item.php?id=117916 (дата посещения: 26.09.2020) 
9. Игры ХІХ летней Олимпиады, проходившие в высокогорном Мехико, принесли советской сборной общекомандное второе место, а всему человечеству - ряд фантастических результатов. https://www.gazeta.ru/sport/london2012/history/mexico_1968/ (дата посещения: 27.09.2020)

10.Филатов Юрий Николаевич. http://www.dubossary.ru/page.php?86 (дата посещения: 28.09.2020)

11. Лариса Попова - «Тираспольская Стрела» (часть первая). http://andronprodan.blogspot.com/2017/04/normal-0-false-false-false.html (дата посещения: 29.09.2020)

12.Журавский Николай. https://olympteka.ru/olymp/athlets/profile/68.html (дата посещения: $30.09 .2020)$

13.Олимпийский чемпион по футболу Игорь Добровольский отмечает 50-летний юбилей. https://tass.ru/sport/4510333 (дата посещения: 01.10.2020)

14.Башкатов Юрий. http://ussr-swimming.ru/bio/bashkatov/bashkatov.htm (дата посещения: $01.01 .2020)$

15.Братья Скрябины (1987). http://box-rybnitsa.narod.ru/history.htm (дата посещения: 02.10.2020)

16.Олимпийць с приднестровским характером. https://novostipmr.com/ru/news/19-0623/olimpiycy-s-pridnestrovskim-harakterom (дата посещения: 03.10.2020)

17.Барселона 1992. http://olimp-history.ru/node/353 (дата посещения: 04.10.2020)

18.Родом из Молдовы: Федор Касапу - единственный олимпийский чемпион нашей страны. https://locals.md/2018/rodom-iz-moldovyi-fedor-kasapu-edinstvennyiy-olimpiyskiy-chempion-nasheystranyi/ (дата посещения: 05.10.2020)

19.Вячеслав Горпишин. https://olympteka.ru/olymp/athlets/profile/1495.html (дата посещения: $06.10 .2020)$

20.Олимпийская история: чемпионы, призеры и надежды Молдовы. https://ru.sputnik.md/rio2016/20160727/8333008.html (дата посещения: 06.10.2020)

21.Молдова на Олимпиаде в Атланте 1996: результаты всех спортсменов (с ранжированием по видам спорта). https://olympteka.ru/olymp/country/results_s/41/mda.html (дата посещения: 07.10.2020)

22.Молдова на Олимпиаде в Сиднее 2000: результаты всех спортсменов (с ранжированием по видам сnорта). https://olympteka.ru/olymp/country/results s/43/mda.html (дата посещения: 08.10.2020)

23.Молдова на Олимпиаде в Афинах 2004: результаты всех спортсменов (с ранжсированием по видам спорта) https://olympteka.ru/olymp/country/results s/45/mda.html (дата посещения: 09.10.2020)

24.Молдова на Олимпиаде в Пекине 2008: результаты всех спортсменов (с ранжированием по видам сnорта). https://olympteka.ru/olymp/country/results s/47/mda.html (дата посещения: 10.10.2020)

25.Молдова на Олимпиаде в Лондоне 2012: результаты всех спортсменов (с ранжсированием по видам сnорта). https://olympteka.ru/olymp/country/results s/49/mda.html (дата посещения: 10.10.2020)

26.Молдова на Олимпиаде в Рио-де-Жанейро 2016: результаты всех спортсменов (с ранжированием по видам спорта). https://olympteka.ru/olymp/country/results_s/51/mda.html (дата посещения: 11.10.2020)

27.Николай Журавский, председатель Национального Олимпийского комитета. В: Независимая Молдова от 18. 05. 2007.

28.Николай Журавский: «Через восемь лет Молдова может остаться без олимпийцев». https://www.kp.md/daily/24259/456165/ (дата посещения: 12.10.2020)

29. Николай Журавский: «Mы в ответе за внешнюю политику молдавского спорта». http://www.vedomosti.md/news/Nikolai_Zhuravskii_My_V_Otvete_Za_Vneshnyuyu_Politiku_Moldavskog o_Sporta (дата посещения: 13.10.2020)

30.Молдова: утатистика участия в https://olympteka.ru/olymp/country/profile/mda.html (дата посещения: 20.11.2020) 